\title{
An Empirical Study on Export, Import and Economic Growth in Bhutan
}

\author{
Md. Gazi Salah Uddin \\ Senior Lecturer \\ Department of Business Administration \\ East West University \\ 43, Mohakhali, Dhaka-1212, Bangladesh \\ Mobile: +88 01715201727 \\ Email: gsu@ewubd.edu, rimsust2002@yahoo.com \\ Shibli A. Khan \\ Head, Dept. of English \\ Presidency University \\ 11A, Gulshan-2, Dhaka-1212, Bangladesh \\ Email: $\underline{\text { sak1@live.com }}$ \\ Md. Mahmudul Alam \\ MSc Student \\ Institute for Environment and Development (LESTARI) \\ Universiti Kebangsaan Malaysia \\ 43600 UKM Bangi, Selangor Darul Ehsan, Malaysia \\ E-mail: rony000@gmail.com \\ Tel: +601-62799091
}

\section{Citation Reference:}

Uddin, M.G.S., Khan, S.A., and Alam, M.M. 2010. An Empirical Study on Export, Import and Economic Growth in Bhutan, Indian Development Review, Vol. 8(1), pp. 95-104.

This is a pre-publication copy.

The published article is copyrighted by the publisher of the journal. 


\title{
An Empirical Study on Export, Import and Economic Growth in Bhutan
}

\begin{abstract}
This paper focuses on the casual relationship between export, import and Gross Domestic Product (GDP) for Bhutan using annual data from 1980 to 2005. The Granger causality test and Co-integration Models are employed taking care of stochastic properties of the variables. The co-integration analysis suggests that there is a long-run equilibrium relationship. The results of Granger causality test shows that there is a causal relationship between the examined variables. The causal nexus is unidirectional from export to import and GDP, and GDP to import only. Here export led growth is empirically proven in Bhutan.
\end{abstract}

Key Words: Co-integration, Granger Causality, Export, Import, Economic Growth JEL Classification: C22, F14, F43

\section{Introduction:}

Economists behind the export-led growth hypothesis consider that export can serve as an engine of growth. The increases in the output demand of a country through the growth of export allow the exploitation of economics of scale for an economy. The expansion in exports promotes specialization in the production of export products, which in turn boost the productivity level and cause the general level of skills to rise in the export sector. The pace of economic development of a nation presents one of the most essential issues in economic debate. A nation could accelerate the rate of economic growth by promoting export of goods and services. The volume of import is negatively related to its relative local price and varies positively with aggregate local demand (real GDP growth).

Bhutan is a very small economy in South Asia, but it has rapid economic growth rate of $8 \%$ in $2005,14 \%$ in 2006 , and $22.4 \%$ in 2007. As a landlocked country, Bhutan depends on foreign aids for financing its developmental programmes and establishment costs, where India has been the largest donor of external aid and its main development and trading partner. Bhutan and India signed a free trade agreement in 2008, which allowed Bhutanese imports and exports from third markets to use India as transit without tariffs. Bhutan is an agricultural economy, but it exports electricity, cardamom, gypsum, timber, handicrafts, cement, fruit, precious stones and spices, and imports fuel, lubricants, grain, machinery, vehicles, fabrics and rice. In 2007, the main export partners of Bhutan were India (58.6\%), Hong Kong (30.1\%), Bangladesh (7.3\%); and major import partners were India (74.5\%), Japan (7.4\%) and Sweden $(3.2 \%){ }^{1}$

Bhutan had a relatively large fluctuating deficit in both merchandise trade account and current account with India and other few countries throughout the 1980s and the first half of the 1990s. However, following the rise in electricity export prices in 1996, Bhutan ran a trade surplus with India for two years (1996-1998) which was eventually reversed in 1999 with a trade deficit at $4.6 \%$ of GDP. Due to importing a wide variety of consumer goods including basic food items, petroleum products, and vast capital goods - mostly for infrastructural

1 The World Factbook, CIA. Available at <https://www.cia.gov/library/publications/the-worldfactbook/geos/bt.html> 
investment, the current account deficits has been continued. However, Bhutan is successfully increasing its exports not only electricity to India but also a variety of goods to third countries, such as, Bangladesh, Netherlands, Singapore, and Thailand. It reflects in the figure 1, where the value of real GDP (LY), real exports (LX), and real imports (LM) of Bhutan in ln form depict an upward trend individually.

Figure 1: GDP, Export, and Import of Bhutan (1980- 2005)

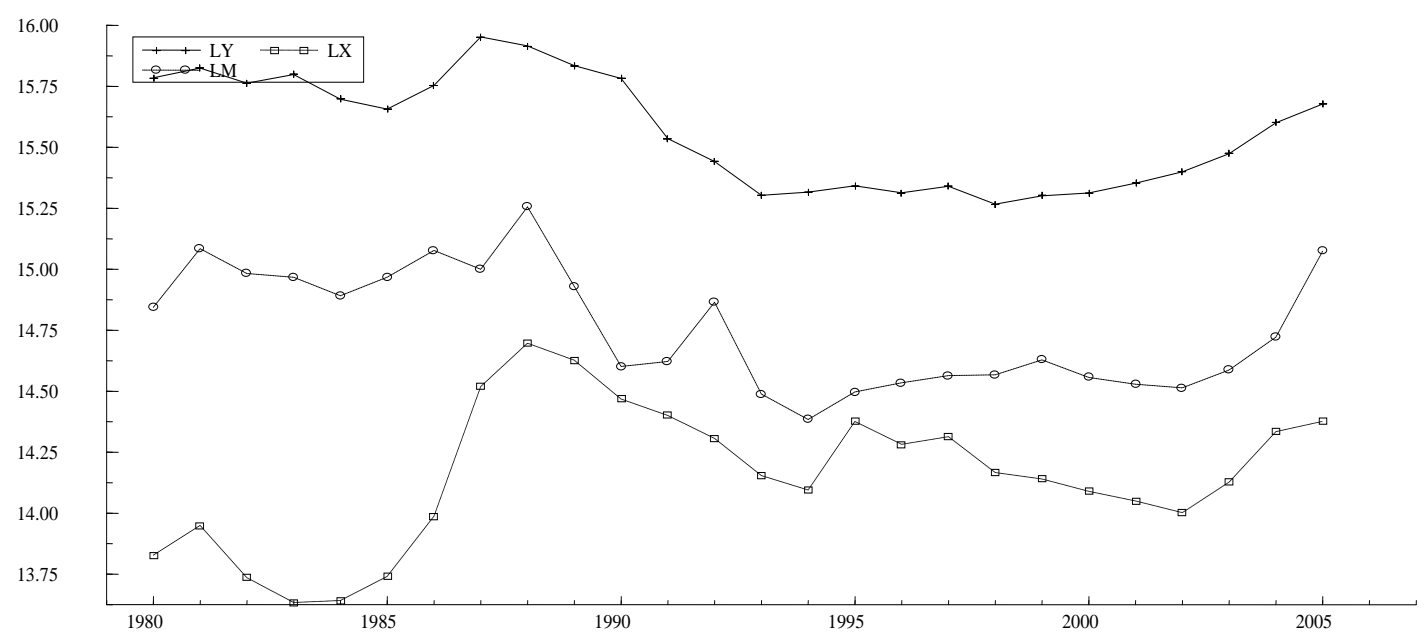

There are very few studies done to measure the economic growth through export and import on Bhutan. This paper is an attempt to carry out an empirical examination of the hypothesis on export-led growth. It also determines the direction of causality between exports, imports and output, and investigates short and long-run dynamic impact of exports, imports on GDP growth in case of Bhutan.

\section{Literature Review}

Strong economic growth accompanied with robust export performance leads many people to conclude that export sector of a country has pivotal role in the economic growth of that country. Export-led growth hypothesis has not only been widely accepted by academics (Feder 1982; Krueger 1990), and evolved into a "new conventional wisdom" (Tyler 1981; Balassa 1985), but it also has shaped the development of a number of countries as well as the policies of the World Bank (World Bank 1987).

However, many evidences fail to unequivocally support a robust export-economic growth nexus. Jung and Marshall (1985), for instance, based on the standard Granger causality tests, analyzed the relationship between export growth and economic growth using time-series data for 37 developing countries and found evidence for the export-led growth hypothesis in only four countries. Darrat $(1986,1987)$ rejects exports-economic growth causality for three out of four countries.

However, seven countries out of a sample of eight newly industrialized countries, Chow (1987) found strong bidirectional causality between export growth and industrial development. Theoretical agreement on export-led growth emerged among neoclassical economists due to the success of the free-market, and outward-oriented policies of the East Asian Tigers (World Bank 1993).

Several researchers- Bahmani-Oskooee, Mohtadi, and Shabsigh (1991) and Dodaro (1993) showed mixed result. Nandi (1991) works on India and finds evidence of unidirectional 
causality from export growth to economic growth. Bhat (1995) re-examines the exporteconomic growth nexus for India, and finds evidence of bi-directional causality between export growth and economic growth. Xu (1996) obtains rejection of the export-led growth hypothesis for India. Ghatak and Price (1997) conclude that export growth is caused by output growth in India.

Khan, et al. (1995) find strong evidence of bi-directional causality between export growth and economic growth for Pakistan. Anwar and Sampath (2000) examine the export-led growth hypothesis for 97 countries (including India, Pakistan and Sri Lanka) for the period 1960-1992. They find evidence of unidirectional causality in the case of Pakistan and Sri Lanka, and no causality in the case of India. However, Kemal, et al. (2002) find a positive association between exports and economic growth for India as well as for other economies of South Asia.

Mamun and Nath (2005) shows industrial production and exports are co-integrated and longrun unidirectional causality from exports to growth in Bangladesh. Love and Chandra (2005) shows both short and long-run unidirectional causality from income to exports in Bangladesh. Clarke and Ralhan (2005), and Mollik (1996) also support causal nexus between export and growth for Bangladesh.

\section{Data and Model Specification}

In this study, annual data of Real GDP, exports, imports, and implicit GDP deflator are taken from World Development Indicator 2007, covering the period 1980-2005 for Bhutan. Export, import and GDP are converted into real terms using the implicit GDP deflator. Since, due to unavailability of price index, the implicit GDP deflator data has been used to obtain the real values of the variables. All data are expressed in logarithms in order to include the proliferate effect of time series and reduce the problem of heteroscedasticity. ${ }^{2}$

In this study, the method of vector autoregressive model (VAR) is adopted to estimate the causal relationship between exports, imports and economic growth in following form:

$$
\mathrm{LY}=\mathrm{f}(\mathrm{LX} \text { and } \mathrm{LM})
$$

Where: $\mathrm{LY}=\ln ($ Gross domestic product $), \mathrm{LX}=\ln$ (Exports), $\mathrm{LM}=\ln ($ Imports $)$

To check stationarity in data, this paper investigates unit root test (Augmented Dickey Fuller and Phillips-Perron). The ADF is widely used due to stability of its critical values as well as its power over different sampling experiment. Perron $(1989,1990)$ has shown that a structural change in the mean of a stationary variable tends to bias the standard ADF tests toward nonrejection of the hypothesis of a unit root. Therefore, this study has conducted Phillips Perron (PP) unit root test along with the ADF test. The test is based on the following regression equation:

$$
\Delta y_{t}=a_{1}+a_{2 t}+b y_{t-1}+\sum_{t=1}^{m} p_{i} \Delta y_{t-1}+\vartheta_{t}
$$

\footnotetext{
${ }^{2}$ Gujrati, D., ‘Basic Econometrics', $3^{\text {rd }}$ Edition 1995, McGraw-Hill
} 
Where, $\Delta y_{t}=Y_{t}-Y_{t-1}$ and $\mathrm{Y}$ is the variable under consideration, $\mathrm{m}$ is the number of lags in the dependent variable chosen by Akaiki Information Criterion and $\vartheta_{t}$ is the stochastic error term. The null hypothesis of a unit root implies that the coefficient of $Y_{t-l}$ is zero.

The co-integration test is possible to carry on after accomplishing the unit root test, in order to examine the existence of a stable long-run relationship between export, import and GDP. To verify co-integrated relationship among the variables, Johansen Co-integration test (Johansen, 1988; Johansen and Juselius, 1990) has been performed only on integrated of order one, i.e. I(1) according to unit root tests, variables. The Johansen method applies maximum likelihood procedure to determine the presence of co-integrating vectors in nonstationary time series as a vector autoregressive (VAR) framework:

$$
\Delta Y_{t}=C+\sum_{i=}^{K} \Gamma_{i} \Delta Y_{t-1}+\Pi Y_{t-1}+\eta_{t}
$$

Where, $\mathrm{Y}_{\mathrm{t}}$ is a vector of non-stationary variables and $\mathrm{C}$ is the constant term. The information on the coefficient matrix between the levels of the $\Pi$ is decomposed as $\Pi=\alpha \beta$ where the relevant elements the $\alpha$ matrix are adjustment coefficient and the $\beta$ matrix contains cointegrating vectors. Johansen and Juselius (1990) specify two likelihood ratio test statistics to test for the number of co-integrating vectors. The first likelihood ratio statistics for the null hypothesis of exactly $\mathrm{r}$ co-integrating vectors against the alternative $\mathrm{r}+1$ vector is the maximum eigenvalue statistic. The second statistic for the hypothesis of at most $r$ cointegrating vectors against the alternative is the trace statistic. Critical values for both test statistics are tabulated in Johansen and Juselius (1990).

To examine the causality for GDP with export and import, Granger causality (Granger 1969, 1988) test was performed only on co-integrated variables. In the absence of any cointegrating relationship between the variables, the standard Granger causality test base on Granger (1988) method can be applied. The Granger method (Granger, 1988) seeks to determine how much of a variable, Y, can be explained by past values of $\mathrm{Y}$ and whether adding lagged values of another variable, $X$, can improve the explanation. Once the Johansen co-integrating test is completed, this study is likely to undertake the Granger causality test to check the casual direction between Economic Growth, exports and imports in Bhutan. The paper is likely to undertake the granger causality test to check the casual direction between exports, imports and economic growth in Bhutan. Some researchers employ first difference VAR framework for checking causality of those variables that are co-integrated (Boulila and Trabelsi, 2004).

\section{Result Analysis:}

In order to obtain a better understanding of the behavior of export, imports and economic growth, the statistical output (Table 1) presents the descriptive statistics for the logarithms of the real export, real import and real GDP. The standard deviation of the export, import and economic growth appear to move closely together.

\begin{tabular}{|l|c|c|c|}
\hline \multicolumn{4}{|c|}{ Table 1: Descriptive Statistics on GDP, Export and Import (Bhutan: 1980-2005) } \\
\hline & LY & LX & LM \\
\hline Mean & 15.56681 & 14.15524 & 14.75885 \\
\hline Median & 15.56791 & 14.14696 & 14.67494 \\
\hline Maximum & 15.95215 & 14.69701 & 15.25640 \\
\hline Minimum & 15.26703 & 13.63321 & 14.38370 \\
\hline
\end{tabular}




\begin{tabular}{|l|c|c|c|}
\hline Std. Dev. & 0.227106 & 0.290287 & 0.242397 \\
\hline Skewness & 0.118986 & -0.138818 & 0.309566 \\
\hline Kurtosis & 1.491100 & 2.303630 & 1.797909 \\
\hline Sum Sq. Dev. & 1.289423 & 2.106659 & 1.468902 \\
\hline Observations & 26 & 26 & 26 \\
\hline
\end{tabular}

The result of unit root test based on both the Augmented Dickey Fuller (ADF) and the Phillips-Perron (PP) tests (Table 2) demonstrates the levels and first difference of the individual variables.

Table: 2 Unit Root Tests (ADF, PP) on GDP, Export and Import (Bhutan: 1980-2005)

\begin{tabular}{|c|c|c|c|c|c|}
\hline \multirow{2}{*}{ Variables } & \multicolumn{2}{|c|}{$\begin{array}{l}\text { Augmented Dickey Fuller } \\
\text { (ADF) }\end{array}$} & \multicolumn{2}{|c|}{ Phillips-Perron (PP) } & \multirow{2}{*}{$\begin{array}{l}\text { Order of } \\
\text { Integration }\end{array}$} \\
\hline & Level & $1^{\text {st }}$ Diff. & Level & $1^{\text {st }}$ Diff. & \\
\hline LX & -2.310917 & $-3.168738 * *$ & -1.910051 & $-3.168738 * *$ & $\mathrm{I}\{1\}$ \\
\hline LM & -1.655658 & $-4.673034 * * *$ & -1.617567 & $-4.649557 * * *$ & $\mathrm{I}\{1\}$ \\
\hline LY & -1.718862 & $-3.083825 * *$ & -1.406542 & $-3.070223 * *$ & $\mathrm{I}\{1\}$ \\
\hline
\end{tabular}

The results of unit root test, both $\mathrm{ADF}$ and $\mathrm{PP}$, indicate that at level values none of the variables are stationary. However, at first differences of the variables, both ADF and PP test indicate that export and GDP are statistically significant at 5\% significance level, and imports are statistically significant at $1 \%$ significance level. Since, first degree differentiation produces stationarity, the variables - LX (real exports), LM (real imports), LY (real GDP) are integrated of order one - I(1).

Since the variables are integrated of order 1, i.e. I(1), now this paper tests whether they are co-integrated or not (Table 3). The Johanson test statistics show rejection for the null hypothesis of no co-integrating vectors under both the trace and maximal Eigen value forms of the test. In case of the trace test, the null of no co-integrating vectors is rejected since the test statistic of 40.08 is greater than the $5 \%$ critical value of 21.13 . Moving on to test the null of at most 1 co-integrating vectors, the trace statistic is 14.54 , while the $5 \%$ critical value is 14.26 , so that the null hypothesis is just rejected at 5\%. Moving on to test the null of at most 2 co-integrating vectors, the trace statistic is 2.43 , while the $5 \%$ critical value is 3.84 , so the null hypothesis is not rejected at 5\%. Finally, results indicate the existence of at least one cointegrating relationship among the variables in the series.

\begin{tabular}{|c|c|c|c|c|c|c|}
\hline \multicolumn{7}{|c|}{ Table: 3 Output for Eigen Value Test and Trace Statistics (Bhutan: 1980- 2005) } \\
\hline $\begin{array}{c}\text { Hypothesized } \\
\text { No. of CE(s) }\end{array}$ & Eigenvalue & $\begin{array}{c}\text { Trace } \\
\text { Statistics }\end{array}$ & $\begin{array}{c}\mathbf{5 \%} \\
\text { Critical } \\
\text { Values }\end{array}$ & $\begin{array}{c}\text { Max- } \\
\text { Eigen } \\
\text { Statistic }\end{array}$ & $\begin{array}{c}\mathbf{5 \%} \\
\text { Critical } \\
\text { Values }\end{array}$ & p-value \\
\hline None* (0) & 0.654925 & 40.08359 & 29.79707 & 25.53584 & 21.13162 & 0.0112 \\
\hline At most 1 (1) & 0.396203 & 14.54775 & 15.49471 & 12.10840 & 14.26460 & 0.1066 \\
\hline At most 2 (2) & 0.096645 & 2.439349 & 3.841466 & 2.439349 & 3.841466 & 0.1183 \\
\hline $\begin{array}{l}\text { Notes: (i) Figures in Max-eigenvalue test indicates 2 co-integrating eqn(s) at the 0.05 level, } \\
\text { (ii) * denotes rejection of the hypothesis at the 0.05 level }\end{array}$ \\
\hline \multicolumn{7}{|l}{} \\
\hline
\end{tabular}


Table 4 presents the long-run equation, which is derived by normalizing on output based on the estimated co-integration coefficient. As expected all the signs are positive indicating that both exports and imports contribute positively to economic growth for Bhutan.

$$
\boldsymbol{L} \boldsymbol{Y}=\boldsymbol{\beta}_{\mathrm{O}}+\boldsymbol{\beta}_{1} \boldsymbol{L X}+\boldsymbol{\beta}_{1} \boldsymbol{L M}+\boldsymbol{u}_{t}
$$

Table: 4 Statistical Output of Export and Import on GDP of Bhutan (1980 - 2005) (EQ 4)

\begin{tabular}{|l|l|l|l|l|}
\hline Model & Coefficient & t-value & p-value & \multirow{2}{*}{$\mathbf{R}^{2}$} \\
\cline { 1 - 4 } Constant & 3.12830 & 1.57 & 0.129 & \multirow{2}{*}{0.724058} \\
\cline { 1 - 2 } & 0.04670 & 0.54 & 0.591 & \\
\hline LM & 0.79799 & 7.77 & 0.000 & \\
\hline
\end{tabular}

$$
L Y=3.128+0.046 L X+0.797 L M+u_{t}
$$

The existences of at least one co-integrating relationship among the variables in the series allow to run standard Granger causality test to find out any causal relationship between exports, imports and economic growth. To find out the causal relationship between the variables, which are non-stationary, the data series should be transformed into stationary (Oxley and Greasley, 1998). It has been confirmed that Granger causality test are well specified if they are applied in a standard vector autoregressive form to differenced data for non co-integrated variables (MacDonald and Kearney, 1987; Miller and Russek, 1990; Lyons and Murinde 1994). Otherwise, the inference from the F-statistics might be spurious because the test statistics will have nonstandard distributions. Therefore, it has been transformed the

\begin{tabular}{|c|c|c|c|c|c|c|}
\hline \multicolumn{7}{|c|}{ Table: 5 Granger Causality Test on GDP, Export and Import (Bhutan: 1980- 2005) } \\
\hline \multirow{2}{*}{ Null Hypothesis } & \multicolumn{2}{|c|}{$\mathrm{K}=1$} & \multicolumn{2}{|c|}{$K=2$} & \multicolumn{2}{|c|}{$\mathbf{K}=\mathbf{3}$} \\
\hline & $\begin{array}{c}\text { F- } \\
\text { Statistic }\end{array}$ & Probability & $\begin{array}{c}\text { F- } \\
\text { Statistic }\end{array}$ & Probability & $\begin{array}{c}\text { F- } \\
\text { Statistic }\end{array}$ & Probability \\
\hline $\begin{array}{c}\text { LX does not Granger } \\
\text { Cause LY }\end{array}$ & 3.80677 & $0.06390 * *$ & 2.89800 & $0.07971 *$ & 4.70669 & $0.01536 * * *$ \\
\hline $\begin{array}{l}\text { LY does not Granger } \\
\text { Cause LX }\end{array}$ & 0.24773 & 0.62362 & 0.24229 & 0.78722 & 0.81656 & 0.50340 \\
\hline $\begin{array}{c}\text { LM does not Granger } \\
\text { Cause LY }\end{array}$ & 1.47249 & 0.23782 & 1.76014 & 0.19893 & 1.20614 & 0.33942 \\
\hline $\begin{array}{l}\text { LY does not Granger } \\
\text { Cause LM }\end{array}$ & 5.16729 & $0.03313 * *$ & 4.44240 & $0.02613 * *$ & 2.69361 & $0.08089 *$ \\
\hline $\begin{array}{l}\text { LM does not Granger } \\
\text { Cause LX }\end{array}$ & 0.04002 & 0.84328 & 0.83321 & 0.44992 & 0.04002 & 0.84328 \\
\hline $\begin{array}{l}\text { LX does not Granger } \\
\text { Cause LM }\end{array}$ & 1.42728 & 0.24493 & 5.97191 & $0.00972 * * *$ & 1.42728 & 0.24493 \\
\hline $\begin{array}{l}\text { Notes: } * * *, * * * \text { indicate } \\
\text { significance level respec } \\
\text { test. }\end{array}$ & $\begin{array}{l}\text { ection of } \\
y \text { and, K }\end{array}$ & e null hypot & is (no G & $\begin{array}{l}\text { iger Causalit } \\
\text { length used } \mathrm{i}\end{array}$ & $\begin{array}{l}\text { at } 10 \% \text {, } \\
\text { the grang }\end{array}$ & $\begin{array}{l}6,1 \% \\
\text { causality }\end{array}$ \\
\hline
\end{tabular}
level data series into the first difference data series and used them for causality test.

The output (Table 5) Granger Causality shows a causal relationship between the examined variables. This is the test of erogeneity of dynamic terms where the null hypothesis is that the 
LX does not Granger cause of LY, and LM does not Granger causes LY, and LM does not Granger cause LX. Three alternative lag lengths have been used to see how sensitive the causality tests to desired lag length. The result based on the Granger Causality test at $5 \%$ and $1 \%$ level of significance will help to investigate and give meaningful conclusion. To stay in the safe side, while rejecting the null of Granger Causality Test, higher significance level is better. It is found that export causes GDP at different significant level for different lag length, but not vice versa. Import does not cause GDP, but GDP causes import at different significant level for different lag length. Export cause import only for lag length 2 at $1 \%$ significant level, but import does not cause export at all. So, in overall it is found that export cause both GDP and import, but import does not cause none GDP and export. So, the casual nexus is unidirectional.

\section{Conclusion:}

This paper explores the association between three important component of an economy named as exports, imports and GDP. First of all, this paper applies unit root test to find the stationarity of the data series. The results show that all the data series of the variables are non-stationary at level values, but stationary at integrated order one. Then it applies Johansen procedure to test the possibility of a co-integrating relationship, which shows two cointegrating relationship between exports, imports and GDP. In the existence of any cointegrating relationship, it is possible to move for standard Granger causality test to find out possible causal relationship among the variables. The causal nexus is unidirectional from export to GDP and import, and GDP to import for Bhutan. So, export led growth is empirically proven in Bhutan. Both export and GDP leads to more import. As import does not lead GDP or export, it indicates Bhutan imports mostly consumer durables goods not capital goods. But, imports of Bhutan supposed to lead export and GDP significantly, because Bhutan imports capital goods that used for infrastructural development of the country; Bhutan meaningfully exports the outcomes (e.g. electricity) of this infrastructure. It is expected to be significant in the future.

\section{References}

Anwar, M., and R. Sampath (2000) Exports and Economic Growth. Indian Economic Journal 47:3, 79-88.

Bahmani-Oskooee, Mohsen; Hamid Mohtadi; and Ghiath Shabsigh. (1991). "Exports, Growth and Causality in LDCs: A Re-examination." Journal of Development Economics 36, no.2: 405-15.

Balassa, Bela (1985). "Exports, Policy Choices, and Economic Growth in Developing Countries after the 1973 Oil Shock," Journal of Development Economics 18, no. 1: $23-35$.

Bhat, S. (1995) Export and Economic Growth in India. Artha Vijana 37:44, 350-358.

Boulila, G and Trabelsi, M. (2004) 'The Evidence from Middle East and North African Countries', Review of Middle East Economics and Finance 2(2):123-138

Chow, P. (1987) Causality between Export Growth and Industrial Development: Empirical Evidence from the NICs. Journal of Development Economics 26, 55-63.

Darrat, Ali F. (1986). "Trade and Development: The Asian Experience." Cato Journal 6, no. 2: 695-99.

Darrat, Ali F.. (1987). "Are Exports an Engine of Growth? Another Look at the Evidence." Applied Economics 19, no. 2: 277-83.

Dodaro, Santo. (1993). "Exports and Growth: A Reconsideration of Causality." Journal of Developing Areas 27, no. 2: 227-44. 
Feder, Gershon. (1982). "On Export and Economic Growth." Journal of Development Economics 12, nos. 1-2: 59-73.

Ghatak, Subrata, and Stephen Wheatley Price. (1997). "Export Composition and Economic Growth: Cointegration and Causality Evidence for India." Weltwirtschaftliches Archiv 133, no.3: 538-53

Granger, C. W. J. (1969) 'Investigating Causal Relations by Econometric Models and Cross Spectral Methods', Econometrica 35:424-438

Granger, C. W. J. (1988) 'Some Recent Developments in the Concepts of Causality', Journal of Econometrics, 39:199-211

Johansen, S. (1988) 'Statistical analysis of cointegration vectors'.,Journal of Economic Dynamics and Control 12:231-254.

Johansen, S., and K. Juselius (1990) Maximum Likelihood Estimation and Inference on Cointegration with an Application to Demand for Money. Oxford Bulletin of Economics and Statistics 52, 169-210.

Judith A. Clarke and Mukesh Ralhan, (2005). "Direct and Indirect Causality Between Exports and Economic Output for Bangladesh and Sri Lanka: Horizon Matters," Econometrics Working Papers 0512, Department of Economics, University of Victoria, revised

Jung, W., and P. Marshall (1985) Exports, Growth and Causality in Developing Countries. Journal of Development Economics 18, 1-12.

Kemal, A. R., M. Din, U. Qadir, L. Fernando, and S. Colombage (2002) Exports and Economic Growth in South Asia. A Study prepared for the South Asia Network of Economic Research Institutes.

Khan, A. H.; A. Malik; and L. Hassan. (1995) "Exports, Growth and Causality: An Application

Krueger, Anne O. (1990). Perspectives on Trade and Development. Chicago: University of Chicago Press.

Love, J and Chandra, R. (2005), "Testing export-led growth in Bangladesh in a multivariate VAR framework", Journal of Asian Economics, Vol. 15, Issue 6, pp.1155-1168

Lyons, S. E., \& Murinde, V. (1994), "Cointegrated and Granger causality testing of hypothesis on supply leading and demand following finance", Economic Note, Vol. 23, pp.17-36

MacDonald, R., \& Kearney, C. (1987), “ On the specification of Granger causality tests using the cointegration methodology", Economic Letters, Vol. 25, pp.149-153.

Mamun, K. A. Al and Nath, H. K. (2005), "Export-led growth in Bangladesh: a time series analysis", Applied Economics Letters, Vol.12, Issues 6, pp.361 -364

Miller, S. M., \& Russek, F. S. (1990), "Co-integration and error correction models: the temporal causality between government taxes and spending", Southern Economic Journal, Vol. 57, pp.221-229.

Mollik, A. (1996) Export Led Growth and Causality in Bangladesh. Asian Economic Review 38:2, 297-307.

Nandi, Sukumar, and Basuded Biswas. (1991). "Export and Economic Growth in India: Empirical Evidence." Indian Economic Journal 38, no. 3: 53-59.

Oxley, L., \& Greasley, D. (1998), "Vector autoregression, cointegration and causality: testing for causes of the British industrial revolution", Applied Economics, Vol. 30, pp. 13871397

Perron, P (1989) 'The Great Crash, the Oil Price Shock, and the Unit Root Hypothesis' Econometrica 57( 6):1361-1401 
Perron, P (1990) 'Testing for a Unit Root in a Time Series with a Changing Mean' Journal of Business \& Economic Statistics 8( 2) :153-162

Tyler, William G. (1981). "Growth and Export Expansion in Developing Countries: Some Empirical Evidence.” Journal of Development Economics 9, no. 1: 121-30.

World Bank. (1987). World Development Report 1987. New York: Oxford University Press

World Bank. (1993). The East Asian Miracle: Economic Growth and Public Policy. New York: Oxford University Press

Xu, Z. (1996) On the Causality between Export Growth and GDP Growth: An Empirical Reinvestigation. Review of International Economics 4:2, 172-184. 